\title{
PENGEMBANGAN MODUL AKIDAH AKHLAK BERBASIS KOMIK KELAS V SEMESTER I DI MI THAWALIB PADANG PANJ ANG
}

\author{
${ }^{1}$ Susi Fitria, ${ }^{2}$ Suswati Hendriani, ${ }^{3}$ Ridwal Trisoni. \\ ${ }^{1}$ MI Thawalib Padang Panjang, ,3/AIN Batusangkar \\ Jln. Abu Hanifah Kampuang Jambak Guguk Malintang Padang Panjang, Sumatera Barat \\ e-mail: ${ }^{1}$ susifitria1976@gmail.com, ${ }^{2}$ suswatihendriani@iainbatusangkar.ac.id, \\ 3ridwaltrisoni@iainbatusangkar.ac.id
}

\begin{abstract}
This study begins with a preliminary study that the Akidah Akhlak lessons in MI Thawalib Padang Panjang are still teacher center, less interesting learning and limited teaching materials in learning so that students have difficulty understanding the Akidah Akhlak subject matter in the sentence material Tayyibah and Asmaul Husna. This will affect the achievement of learning objectives to the maximum and learning outcomes that increase. This study aims to develop a comic-based learning module in the subjects of the Akidah Akhlak Tayyibah and Asmaul Husna sentence material that are valid. This type of research is development research that uses stages of the 4-D model, namely defining, designing, developing, and disseminating Learning Modules validated by 3 validators. Based on the research conducted, a comic-based module was produced in the Akidah Akhlak subjects in the Tayyibah and Asmaul Husna sentence material. The results of the validation of comic-based learning modules were assessed by 3 (three) validators, the average results of the overall validation were $84.2 \%$ in the very valid category.
\end{abstract}

Keywords: Modul, Akidah Akhlak

\section{PENDAHULUAN}

Pembelajaran suatu rangkaian kegiatan belajar yang akan dilalui setiap manusia, pembelajaran merupakan proses dari yang tidak paham menjadi paham, dari yang tidak tahu menjadi tahu dan akan terjadinya perubahan pada tingkah laku dari hasil rangkaian kegiatan belajar tersebut. Proses pembelajaran tidak hanya menuntut siswa pintar dalam akademik tetapi juga dalam perubahan dalam tingkah laku yang akan berguna bagi siswa dalam menjalani kehidupannya.

Pembelajaran adalah kegiatan yang bertujuan membelajarkan siswa. Proses pembelajaran itu merupakan rangkaian kegiatan yang melibatkan berbagai komponen. Proses pembe- 
lajaran harus dilakukan pemanfaatan setiap komponen dalam proses kegiatan untuk mencapai tujuan pembelajaran. Pendidikan Nasional di Indonesia menurut Undang-Undang RI NO. 20 tahun 2003, Bab I, pasal I bahwa pendidikan adalah usaha sadar dan terencana untuk mewujubkan suasana belajar dan proses pembelajaran agar peserta didik secara aktif mengembangkan potensi dirinya untuk memiliki kekuatan spiritual keagamaan, pengendalian diri kepribadian kecerdasan, akhlak mulia serta keterampilan yang diperlukan dirinya, masyarakat, bangsa dan negara. (Daryanto, 2017: 27).

Menghadapi minat siswa belajar guru dituntut lebih kreatif untuk mengembangkan bahan ajar sehingga membangkitkan kembali semangat siswa dalam proses pembelajaran. Guru harus menguasai asas pendidikan dan teori pendidikan dan yang lebih penting mengetahui karakteristik siswa sekolah dasar sehingga solusi yang diberikan tepat guna.

Berdasarkan hasil observasi di MI Thawalib Padang Panjang bahwa belum tersedianya bahan ajar berupa modul pada mata pelajaran Akidah Akhlak, kurangnya ketersediaan buku paket dan buku pendukung di sekolah tersebut, sehingga proses pembelajaran bersifat fasif dan masih berpusat pada guru. (Observasi, Padang Panjang: 1 September 2018).
Analisis bahan ajar yang penulis lakukan adalah terdapatnya kekurangan dari bahan ajar tersebut, tidak adanya gambar penunjang yang menarik bagi siswa, buku hanya memiliki warna hitam putih, tidak ada paduan warna yang menarik.

Kualitas bahan ajar yang rendah akan berakibat rendahnya perolehan prestasi belajar siswa. Selain itu pergeseran guru yang awalnya sebagai sumber belajar satu-satunya dan saat ini mengarah sebagai fasilitator menuntut kehadiran sebuah bahan ajar agar menjembatani permasalahan keterbatasan kemampuan daya serap siswa di kelas. Pentingnya kehadiran bahan ajar dapat berguna untuk memahami dan memberikan perlakuan sesuai dengan karakteristik siswa secara individual, menjembatani persoalanrendahnya aktualisasi diri siswa, sehingga materimateri yang kurang dipahami dapat dieksplorasi kembali melalui bahan ajar. (Lestari, 2013: 1).

Pentingnya bahan ajar yang relevan sesuai kebutuhan siswa bahwa, siswa berasal dari suatu kelompok masyarakat yang memiliki keanekaragaman sosial budaya dan kondisi ekonomi akan mewarnai struktur mentalnya akan berpengaruh pada proses pembelajaran dan hasil belajar yang akan dicapai. Usaha untuk meningkatkan prestasi belajar siswa dapat dilakukan dengan bahan ajar yang sesuai dengan kurikulum 
dan karakteristik siswa salah satunya bahan ajar modul.

Modul merupakan bahan ajar yang ditulis dengan tujuan agar siswa dapat belajar secara mandiri tanpa bimbingan guru, oleh karena itu, modul harus berisi tentang petunjuk belajar, kompetensi yang akan dicapai, isi materi pelajaran, informasi pendukung, latihan soal, petunjuk kerja, evaluasi. Pemberian modul siswa dapat mandiri dalam belajar tanpa di bantu oleh guru. Siswa yang belajarnya lambat dapat berkali-kali mempelajari tanpa terbatas oleh waktu, sedangkan siswa yang belajarnya cepat sehingga lebih cepat menguasai materi pelajaran. Jadi modul sangat mewadahi kecepatan siswa belajar yang berbeda-beda. Jadi dapatlah disimpulkan bahwa modul seperangat bahan ajar yang berisi komponen-komponen yang komplek yang mencakup tujuan pembelajaran sehingga memudahkan siswa mempelajari dan memahami materi yang telah dibahas di kelas. (Lestari, 2013: 6).

Dalam mengembangkan bahan ajar sangat erat kaitannya dengan karakteristik siswa apalagi siswa sekolah dasar atau setingkat dengan madrasah, bagaimana guru mampu mengemas pembelajaran itu menarik dan menyenangkan, dan tidak membosankan, bagaimana guru dapat menyajikan pembelajaran tersebut bermain sambil belajar sesuai tingkat usia siswa Sekolah Dasar.

Mata pelajaran yang dijadkan fokus pengembangan adalah mata pelajaran Akidah Akhlak. Akidah adalah Akidah berisikan ajaran tentang apa yang harus dipercayai, diyakini, dan diimani oleh setiap muslim. Agama Islam bersumber kepada kepercayaan dan keimana kepada Allah, maka akidah merupakan sistem kepercayaan yang mengikat manusia kepada Islam. Seorang manusia disebut muslim ketika dengan penuh kesadaran dan ketulusan orang tersebut bersedia terikat dengan system kepercayaan Islam dan tampak dalam perilaku sehari-harinya.(Mahmud, 2011: 12).

Prinsip akhlak dalam Islam yang paling menonjol adalah bahwa manusia bebas melakukan tindakantindakannya, manusia mempunyai kehendak untuk berbuat dan tidak berbuat sesuatu. Tanggung jawab pribadi merupakan prinsip akhlak yang paling menonjol dalam Islam dan semua urusan keragaman seseorang selalu disandarkan pada tanggung jawab pribadi. Ciri khas akhlak Islam adalah kelengkapan dan luas bidangnya yang meliputi semua aspek perbuatan manusia sama ada mengenai dirinya, orang lain atau yang berkaitan dengan perseorangan atau kemasyarakatan dan kenegaraan. Tidak ada suatu pun perbuatan mannusia yang keluar dan tidak 
diatur oleh peraturan akhlak Islam. (Mukni'ah, 2011: 109).

Alasan penulis melakukan penelitian modul berbasis komik ini adalah karena komik sangat di senangi anak-anak, untuk usia anak sekolah dasar yang memiliki karaktersitik masih usia bermain. komik merupakan bacaan ringan dan menghibur. Alangkah menariknya media komik ini dipadukan dengan materi pelajaran sehingga siswa lebih tertarik dan menumbuhkan minat siswa untuk belajar.

Dari pengamatan penulis siswa lebih suka buku bacaan berupa komik. Penulis bertanya ke salah satu siswa kenapa memilih buku bacaan yang disukai itu komik kenapa tidak buku Islami berupa cerita teladan para nabi dan rasul. Salah satu siswa menjawab buku cerita komik menarik, bukunya berwarna dan kalimatnya pendek-pendek. Jadi dari sinilah penulis memiliki ide untuk mengembangkan bahan ajar berupa Modul Berbasis Komik. Dengan alasan inilah penulis melakukan penelitian Pengembangan bahan ajar Modul Berbasis Komik pada mata pelajaran Akidah Akhlak dengan materi Kalimat Thayyibah dan Asma'ulHusna di kelas V MI di Thawalib Padang Panjang.

Komik salah satu media baca yang sangat digemari oleh anak-anak, karena komik merupakan cerita bergambar dengan gambar dan paduan warna yang menarik di tambah tokoh-tokoh yang unik dan lucu, di lengkapi balon kata dengan kalimat yang singkat dan tepat sesuai dengan pemahaman anak, dan anak pun tidak bosan membaca. Malahan komik dapat membantu anak dan memotivasi anak untuk gemar membaca.

\section{KAJIAN TEORI}

\section{Konsep Modul}

Secara bahasa, kata modul diambil dari Bahasa Inggris "module" yang berarti "unit, bagian, atau juga bermakna kursus, latihan, pelajaran berupa kursus yang besar." Dalam kamus Bahasa Indonesia modul berarti "unit usaha kecil dari satu pelajaran yang dapat beroperasi sendiri." Jadi modul bermakna kumpulan satu unit program belajar mengajar terkecil yang terinci yang terdapat pada komponen-komponen modul. (Ramayulis, 2012: 183).

Menurut Walter Dick dan Lou Carey mengatakan bahwa Modul adalah satuan unit pembelajaran berbentuk cetak, mengajar secara terpadu dan memiliki satu tema terpadu dan disajikan kepada siswa dengan keterangan-keterangan yang diperlukan untuk menguasai dan menilai pengetahuan dan ketrampilan yang ditentukan dan berfungsi sebagai satu komponen dari seluruh 
kurikulum. (Syafruddin Nurdin, 2016: 272)

Menurut para pakar di atas dapat dianalisis bahwa modul merupakan suatu rangkaian belajar yang merupakan bahan pembelajaran yang dapat digunakan siswa sebagai sumber belajar dalam proses pembelajaran, dalam pembahsan ini penulis memberikan modul pada pembelajaran akidah akhlak berbasis komik sehingga siswa semangat dalam belajar.

\section{Konsep Komik}

Komik adalah suatu kartun yang mengungkapkan sutau karakter dan memerankan suatu cerita dalam urutan yang erat, dihubungkan dengan gambar dan dirancang untuk memberi hiburan kepada para pembaca. Komik adalah suatu bentuk berita bergambar terdiri atas berbagai situasi cerita bersambung kadang bersifat humor. Komik adalah susunan gambar dan kata-kata untuk menceritakan sesuatu atau mendramatisasi sesuatu. Ide komik sebagai gambar-gambar dan lambanglambang lain yang berdekatan dalam urutan tertentu yang bertujuan untuk memberikan informasi atau mencapai tanggapan dari para pembaca. (Rohani, 2014: 78).

Komik suatu bentuk cerita bergambar dan gambarnya tersebut berbentuk kartun yang dibuat dengan ilustrasi gambar, kalimatnya dibuat singkat dan padat yang dikemas dalam bentuk balon kata. Gambar dibubuhi dengan warna-warnya yang menarik sehingga sangat diminati oleh kalangan siswa.

Peranan pokok komik dalam instruksional adalah kemampuannya dalam menciptakan minat siswa. Penggunaan komik sebaiknya dipadu dengan metode mengajar, sehingga komik menjadi alat yang efektif, sehingga bisa membimbing dan menarik minat baca siswa. Komik suatu bacaan diman siswa membaca tanpa harus di bujuk. Dengan bimbingan guru komik dapat berfungsi sebagai jembatan untuk menumbuhkan minat baca siswa. Guru harus dapat menemukan komik edukatif dan bermanfaat bagi siswa dan membantu mereka menuju cakrawala yang lebih luas.Walaupun komik dapat menumbuhsuburkan minat baca siswa tetapi jangan sampai terlena sehingga lupa membaca buku pelajaran. (Rohani, 2014: 79).

Cerita komik bergambar bisa meransang siswa untuk membaca. Cerita komik dibuat kalimat yang sederhana, mudah dipahami dan ceritanya dibuat lucu sesuai dengan kebutuhan siswa. Jadi komik bisa memotivasi anak-anak yang tadinya malas membaca akhirnya jadi gemar membaca. 


\section{METODE PENELITIAN}

Penelitian ini dirancang sebagai penelitian Research and Development (RED). Metode penelitian dan pengembangan dapat diartikan sebagai cara ilmiah untuk meneliti, merancang, memproduksi dan menguji validitas produk yang telah dihasilkan. (Sugiyono, 2017: 30). Penelitian yang dilakukan adalah tentang Pengembangan Modul Akidah Akhlak Berbasis Komik pada Materi Kalimat Thayyibah dan Asma'ul-Husna kelas V semester II di MI Thawalib Padang Panjang. Adapun dari segi pendekatan yang digunakan penelitian ini menggunakan pendekatan kualitatif. Awal pelaksanaan penelitian pengembangan dengan mengetahui jenis bahan ajar yang digunakan di MI Thawalib Padang Panjang dan kebutuhan terhadap pengembangan bahan ajar.

Prosedur Penelitian Model R\&D yang digunakan dalam penelitian ini adalah model 4D oleh Thiagarajan dan Semmel (1974). Model pengembangan $4 \mathrm{D}$ terdiri atas 4 tahap utama yaitu: Pertama, Define (Pendefenisian), Kedua, Design (Perancangan), Ketiga, Develop (Pengembangan), Keempat, Disseminate (Penyebaran). (Sugiyono, 2017: 37).

\section{HASIL DAN PEMBAHASAN}

\section{Hasil Penelitian}

Pelaksanaan penelitian yang penulis lakukan melalui wawancara yang dilakukan kepada guru akidah akhlak yang bernama ibu Siti Hawa, S.Pd, beliau mengajar kelas $\mathrm{V}$ mengatakan bahwa bahan ajar yang dipakai pada pembelajaran Akidah Akhlak masih kurang menarik bagi siswa dan membosankan, sehingga minat siswa untuk belajar Akidah Akhlak juga rendah. Adapun buku cetak Membina Akidah dan Akhlak kelas V MI, Penerbit Tiga Serangkai masih kurang mendukung untuk menjadikan sebuah pembelajaran yang menarik dan menyenangkan bagi siswa. Sekolah juga memiliki bahan ajar berupa modul konvensional yang sudah jadi tetapi masih bersifat monoton dan tidak terlalu disukai oleh siswa karena hanya memuat soal-soal yang akan dikerjakan.

\section{Silabus}

Berdasarkan kurikulum 13 silabus pembelajaran Akidah Akhlak kelas $\mathrm{V}$ semester I terdiri dari : kompetensi Inti, standar kompetensi yaitu memahami Kalimat Thayyibah Alhamdulillah dan Allahu Akbar. Kompetensi dasar yaitu meyakini kebesaran Allah SWT melalui kalimat Thayyibah Alhamdulillah dan Allahu 
Akbar. Materi Kalimat Tayyibah terdiri dari 4 indikator yaitu 1). Menyebutkan Kalimat Thayyibah Alhamdulillah Dan Allahu Akbar, 2). Mengartikan Kalimat Thayyibah Alhamdulillah Dan Allahu Akbar, 3). Menunjukan contoh penggunaan lafal Kalimat Thayyibah Alhamdulillah Dan Allahu Akbar, 4). Terbiasa mengucapkan kalimat Thayyibah Alhamdulillah Dan Allahu Akbar.

Materi Asmaul Husna kompetensi inti, standar kompetensi yaitu memahami Asmaul Husna Ar-Razzaq, Al-Mugni, Al-fattah, Asy-Syakur. Komptensi dasar yaitu meyakini kebesaran Allah SWT melalui Asmaul Husna Ar-Razzaq, Al-Mugni, Al-fattah, Asy-Syakur. Materi Asmaul Husna terdiri dari 4 indikator yaitu 1). Menyebutkan Asmaul Husna ArRazzaq, Al-Mugni, Al-fattah, AsySyakur, 2). Mengartikan Asmaul Husna Ar-Razzaq, Al-Mugni, Al-fattah, AsySyakur, 3). Menunjukan contoh sederhana bahwa Allah bersifat Asmaul Husna Ar-Razzaq, Al-Mugni, Al-fattah, Asy-Syakur, 4). Menunjukan perilaku beriman terhadap Asmaul Husna Ar-Razzaq, Al-Mugni, Al-fattah, Asy-Syakur.

Materi Kalimat Thayyibah Alhamdulillah dan Allahu Akbar, materi Asmaul Husna yang terdapat dalam silabus mata pelajaran Akidah Akhlak ada kesesuaian antara standar kompetensi dan kompetensi dasar dan dapat dikembangkan sesuai dengan tujuan pembelajaran.

\section{Analisis Siswa}

Analisis siswa dilakukan untuk memberikan jalan keluar setiap permasalahan yang di hadapi siswa dalam proses pembelajaran. Permasalahan yang dihadapi siswa seperti rasa bosan dan jenuh dalam belajar karena bahan ajar yang kurang menarik dan bahan ajar yang kurang lengkap, guru yang masih mengajar dengan cara yang lama seperti masih memakai metode ceramah, guru yang masih belum peka terhadap perubahan. Dengan adanya Modul Akidah Akhlak Berbasis Komik bisa menjawab permasalahan yang dihadapi siswa dan memberi jalan keluar supaya siswa bisa belajar dengan cara menyenangkan.

Usia sekolah tingkat dasar siswa lebih senang dengan buku yang memiliki gambar yang menarik ditambah lagi dengan paduan warna gambar yang disukai siswa sehingga meransang minat siswa untuk belajar dan semangat belajar siswa pun meningkat. Sesuai dengan Teori Jean Piaget dalam pembelajaran. (Anwar, 2017: 332) bahwa siswa bisa belajar dengan baik jika ia aktif mencari solusi secara mandiri. Metode belajarnya adalah dengan bereksperimen mencari hal-hal baru dan disuguhi metode yang bisa menarik 
minatnya untuk belajar serta menjauhi metode ceramah yang membuat siswa bosan.

\section{Analisis Buku Paket Akidah Akhlak}

Analisis buku paket yang dilakukan di sekolah tersebut adalah buku paket Akidah Akhlak Pendekatan Kurikulum 2013, dengan judul buku Membina Akidah dan Akhlak kelas V MI, Penerbit Tiga Serangkai, bahwa buku paket tersebut tidak mencukupi dengan jumlah siswa di madrasah dan pembahasan materi pada buku paket Akidah Akhlak yang di pakai terlalu luas siswa kesulitan untuk memahaminya. Buku paket tersebut belum mampu menarik minat belajar siswa karena hanya berupa bacaan dan tidak ada gambar-gambar penunjang yang berwarna menarik. Belum adanya bahan ajar yang mendukung proses pembelajaran di sekolah tersebut.

Oleh sebab itu Modul Akidah Akhlak Berbasis Komik ini dirancang untuk memenuhi kekurangan dan mengatasi permasalahan yang terjadi di madrasah tersebut dan bisa membangkit minat siswa lebih semangat dalam belajar karena Modul Komik yang dirancang sesuai selera siswa ditingkat Madrasah Ibtidaiyyah karena gambar komik dan paduan warna komik yang menarik. Sesuai hasil respon siswa yang didapat dari hasil penelitian yang telah dilakukan.

\section{Pembahasan}

\section{Tahap Pendefenisian (Define)}

Hasil wawancara penulis dengan guru Akidah Akhlak penulis memberikan Modul Akidah Berbasis Komik beliau menyampaikan pandangan positif bahwa Modul Akidah Akhlak Berbasis Komik ini menarik dan cocok untuk pembelajaran Akidah Akhlak, modul komik ini akan menarik bagi siswa dan bisa meningkatkan minat siswa pada pembelajaran Akidah Akhlak ke depannnya.

Untuk terwujudnya iklim dan proses pembelajaran yang kondusif perlu didukung oleh berbagai faktor, baik berkenaan dengan kemampuan guru, misalnya dalam memilih bahan ajar. (Aunurrahman, 2012: 79). Modul adalah satu kesatuan program yang lengkap, sehingga dapat dipelajari oleh siswa secara individual. Sebagai bahan pelajaran yang bersifat mandiri, maka materi pelajaran yang dikemas sedemikian rupa sehingga melalui modul siswa dapat belajar secara mandiri tanpa terikat oleh waktu tempat dan hal-hal lain diluar diri siswa sendiri. (Wina Sanjaya, 2012: 155).

Modul Akidah Akhlak Berbasis Komik bisa menjawab permasalahan yang dihadapi siswa dan memberi jalan keluar supaya siswa bisa belajar dengan semangat dan menyenang- 
kan. Pembahasan materi pada buku paket Akidah Akhlak yang di pakai terlalu luas siswa kesulitan untuk memahaminya. Oleh sebab itu modul Akidah Akhlak ini di rancang untuk memenuhi kekurangan dan mengatasi permasalahan yang terjadi di madrasah tersebut.

\section{Perancangan (Design)}

Tahap perancangan ini dilakukan setelah melalui tahap pendefenisian. Pada tahap perancangan ini yang pertama dirancang adalah cover modul dan paduan warna yang dipakai pada cover. Backround modul di desain dengan Aplikasi Indesign supaya tampilan modul lebih menarik dan gambar komik dibuat dengan Aplikasi Illustator. Cover bertemakan siswa belajar kelompok dengan suasana yang menyenangkan dan cover di beri warna biru sehingga cover terkesan lembut dan tenang. Warna biru merupakan warna yang agak terlalu menenangkan bagi lingkungan pembelajaran. Sebuah studi mencoba mengukur isyarat verbal terhadap warna dalam pembelajaran. Dalam ujian memori verbal dan memori warna dapat diketahui bahwa para pelajar lebih baik mengingat warna. (Syaifurahman, 2013: 124).

Modul Akidah Akhlak Berbasis Komik di rancang untuk meningkatkan gairah siswa belajar terutama mata pelajaran Akidah Akhlak. Siswa tidak lagi bosan dan jenuh ketika proses pembelajaran berlangsung. Modul Akidah Akhlak Berbasis Komik di rancang mulai dari cover, petunjuk guru dan siswa, tersedia SK, KD, KI, indikator, dan tujuan pembelajaran. Materi disuguhi dengan cerita komik supaya siswa tertarik, untuk menambah pemahaman siswa modul juga dilengkapi dengan soal-soal latihan. Modul juga dirancang sesuai kurikulum 13 sekaligus menampilkan penilaian sikap. Di akhir modul dilengkapi kunci jawaban.

\section{Tahap Pengembangan (Develop)}

1) Analisis Validasi

Modul Akidah Akhlak Berbasis Komik menurut 3 pakar sangat valid dengan persentase 84,2\%. Kevalidan Angket Respon Guru Pelaksanaan Pembelajaran dengan Modul Akidah Akhlak Berbasis Komik 86,6\% dengan kategori sangat valid. Aspek penilaian yang terdiri dari format angket 83,3\% sangat valid, bahasa yang digunakan $87,5 \%$ sangat valid, butir pernyataan angket $87,5 \%$ sangat valid.

Penelitian yang releven dengan Modul Akidah Akhlak Berbasis Komik ini adalah Modul Komik Tematik Multiple Intellegence oleh Arlenia Dwi Yasa, 2017 mengatakan bahwa kevalidan produk sebesar 95,04\% dengan criteria sangat valid. 
Kevalidan Angket Respon Siswa Pelaksanaan Pembelajaran dengan Modul Akidah Akhlak Berbasis Komik 86,6\% dengan kategori sangat valid. Aspek penilaian yang terdiri dari format angket 83,3\% sangat valid, bahasa yang digunakan $83,3 \%$ sangat valid, butir pernyataan angket 83,3\% sangat valid.

Kevalidan Pedoman Wawancara terhadap Modul Akidah Akhlak Berbasis Komik dengan guru mata pelajaran Akidah Akhlak 84,3\% dengan kategori sangat valid. Aspek penilaian terdiri dari pemanasan $86,1 \%$ sangat valid, Lebel-check 83,3\% sangat valid, Probing 75\% valid, Winddown $86,1 \%$ sangat valid.

\section{2). Analisis Praktikalitas}

Hasil analisis angket respon guru terhadap praktikalitas Modul Akidah Akhlak Berbasis Komik 95,31\% dengan kriteria sangat praktis. dengan kriteria sangat praktis. Hasil analisis angket respon siswa terhadap praktikalitas Modul Akidah Akhlak Berbasis Komik 96,55\% dengan kriteria sangat praktis.

\section{Tahap Penyebaran (Dissemination)}

Setelah selesai tahap hasil pengembangan yaitu produk yang telah di validasi dan sudah layak diuji coba, serta melalui revisi-revisi untuk kesempurnaan modul, lanjut tahap penyebaran.

Tahap Penyebaran (Dissemination) berisi kegiatan menyebarluaskan produk yang telah teruji untuk dimanfaatkan orang lain. (Sugiyono, 2017: 38) Pada tahap akhir ini dilakukan produk hasil pengembangan dilakukan proses penyebarluasan sehingga dapat diterima oleh pengguna, baik individu, kelompok. Dalam penelitian ini penyebaran dilakukan terbatas hanya di MI Padang Panjang saja. Hal ini karena keterbatasan biaya peneliti.

\section{PENUTUP}

\section{Kesimpulan}

Penelitian ini merupakan pengembangan modul pemebelajaran berbasis komik pada mata pelajaran Akidah akhlak untuk siswa kelas V MI Thawalib Padang Panjang. Berdasarkan penegmbangan yang telah dilakukan, diperoleh kesimpulan sebagai berikut:

1. Penggunaan sumber belajar pada mata pelajaran Akidah Akhlak kelas V MI Padang Panjang belum memadai karena hanya menggunakan buku paket dan tidak menggunakan sumber belajar lainnya.

2. Permasalahan yang dihadapi guru dan siswa dalam penggunaan sumber belajar pada mata pelajaran Akidah AKhlak kelas V MI Padang Panjang yaitu sumber belajar berupa buku paket belum legkap dan belum bisa meningkatkan motivasi belajar siswa sehingga 
siswa malas untuk mengikuti pembelajaran.

3. Produk tentang modul pembelajaran Akidah Akhlak yang sudah dikembangkan telah nilai oleh 3 (tiga) orang validator dinyatakan sangat valid. Dengan rata-rata validasi secara keseluruhan yang diperoleh 84,2\%. Untuk persentasi aspek materi sebesar 91,7\% dengan sangat valid, aspek penyajian sebesar $86,7 \%$ dengan kategori sangat valid, aspek gambar komik 83,3\% kategori sangat valid, aspek bahasa $75 \%$ kategori valid.

\section{Saran}

Berdasarkan hasil penelitian dan analisis di bab sebelumnya, peneliti perlu memberikan beberapa saran:

1. Kepada guru di MI Thawalib Padang Panjang disarankan untuk menggunakan Modul Akidah Akhlak Berbasis Komik kelas V semester II dengan Materi Kalimat Thayyibah dan Asmaul Husna ini pada proses pembelajaran terutama Mata Pelajaran Akidah Akhlak.

2. Modul Akidah Akhlak Berbasis Komik kelas V semester II dengan Materi Kalimat Thayyibah dan Asmaul Husna di MI Thawalib Padang Panjang dapat dijadikan acuan untuk bahan ajar dalam proses pembelajaran di sekolah.

3. Kepada siswa di MI Thawalib Padang Panjang disarankan untuk menggunakan Modul Akidah Akhlak Berbasis Komik kelas V semester II dengan Materi Kalimat Thayyibah dan Asmaul Husna pada pembelajaran di sekolah.

\section{KEPUSTAKAAN ACUAN}

Al Quran Terjemahan, 2013, Kementerian Agama Republik Indonesia.

Aunurrahman, 2012, Belajar dan Pembelajaran, Bandung: Alfabeta.

Anwar, Chairul, 2017, Teori-Teori Pendidikan Klasik Hingga Kotemporer, Jogjakarta, IRCiSoD.

Daryanto, Syaiful Karim, 2017, Pembelajaran Abad 21, Jakarta: Penerbit Gava Media.

Lestari, Ika, 2013, Pengembangan Bahan Ajar Berbasis Kompetensi Sesuai Dengan Kurikulum, Padang, Akademia Permata.

Mahmud, Dimyati, 2001, Psikologi Suatu Pengantar, Yogyakarta: BPFE

Mukni'ah, 2011, Materi Pendidikan Agama Islam, Jakarta: Ar-Ruzz Media.

Nurdin, Syafruddin,2016, Kurikulum dan Pembelajaran, Depok: PT Raja Grafindo Persada.

Rohani, A, 2014, Media Instruksional Edukatif, Jakarta: PT Rineka Cipta. 
Ramayulis, 2012, Metodologi
Pendidikan Agama Islam,
Jakarta; Kalam Mulia. Sanjaya Wina, 2007, Strategi Pembelajaran, Jakarta: Kencana Prenada Media Grup.

Sugiyono, 2017, Metode penelitian pendidikan pendekatan kuantitatif, kualitatif, dan RED. Bandung: Alfabeta.

Sumantri, Syarif M, 2015, Strategi Pembelajaran: Teori dan Praktek di Tingkat Pendidikan Dasar, Jakarta : Raja Grafindo Persada.

Syaifurahman, 2013, Manajemen dalam Pembelajaran, Jakarta: Penerbit Indeks. 